\title{
SISTEM PENDUKUNG KEPUTUSAN UNTUK MENENTUKAN PENERIMAAN BEASISWA TIDAK MAMPU PROGRAM STUDI SISTEM INFORMASI INIVERSITAS ISLAM INDRAGIRI
}

\author{
${ }^{1}$ Herman Syahputra, ${ }^{2}$ Samsudin \\ 1,2, Program Studi Sistem Informasi, Fakultas Teknik dan IImu Komputer \\ Universitas Islam Indragiri (UNISI) \\ Jl. Provinsi No. 01 Tembilahan Hulu, Indragiri Hilir, Riau - Indonesia \\ Email: sonic.xp88@yahoo.com, samsudinasad@yahoo.co.id
}

\begin{abstract}
Dalam menentukan penerimaan beasiswa tidak mampu pada Prodi Sistem Informasi Universitas Islam Indragiri, ada beberapa kriteria yang harus dimiliki dan dipenuhi oleh para mahasiswa sebagai syarat untuk mendapatkan beasiswa tersebut. Untuk membantu dalam menetapkan seseorang yang layak menerima beasiswa tersebut maka dibutuhkan sebuah sistem pendukung keputusan. Darimaka itu dibuatlah sebuah sistem untuk mendukung dalam pemilihan mahasiswa tidak mampu dengan menggunakan metode Tsukamoto.

Penelitian dilakukan dengan menghitung nilai setiap kriteria mahasiswa, kemudian dilakukan proses perankingan yang nantinya akan menentukan siapa saja yang berhak menerima beasiswa tersebut.
\end{abstract}

Kata Kunci : Fuzzy Tsukamoto, Fuzzy Beasiswa, Sistem Penduknng Keputusan Fuzzy

\section{PENDAHULUAN}

Dengan adanya penerimaan beasiswa yang diberikan oleh Universitas diharapkan akan membantu para mahasiswa. Terlebih bantuan tersebut berupa beasiswa tidak mampu yang mana tujuannya adalah mahasiswa yang benar-benar membutuhkan bantuan dana tersebut.

Untuk mendapatkan beasiswa tersebut, mahasiswa harus memenuhi syarat-syarat yang telah ditetapkan oleh Prodi Sistem Informasi yaitu kriteria-kriteria yang mana nantinya akan menjadi acuan untuk menentukan siapa saja yang berhak menerima beasiswa tersebut.

Dikarenakan tidak semua yang mendaftarkan diri akan diterima, maka dari itu di rancanglah sebuah sistem yang mana akan mendukung ketua Prodi dalam menentukan mahasiswa mana yang benar-benar berhak menerima beasiswa tidak mampu, melalui penilaian kriteria yang telah ditetapkan.

Sistem berbasis komputeriasi dan dengan metode Fuzzy Tsukamoto serta nilai-nilai kriteria yang telah ditetapkan, diharapkan penilaian yang dilakukan lebih transparan dan dapat dipertanggung jawabkan, sehingga mahasiswa yang disarankan oleh sistem adalah mahasiswa yang benar-benar berhak menerima bantuan beasiswa tidak mampu.

Rumusan Masalah penelitian ini yaitu: Keputusan penerimaan beasiswa tidak mampu masih dilakukan dengan secara manual. Keputusan penerimaan beasiswa tidak mampu tidak transparan dikarenakan tidak memiliki sistem dan metode pengambilan keputusan. Keputusan penerimaan beasiswa tidak mampu cukup lama.

Tujuan Penelitian penelitian ini yaitu:Merancang sistem pengambilan keputusan penerimaan beasiswa tidak mampu berbasis komputerisasi. Merancang sistem pengambilan keputusan agar lebih transparan dalam mengambil sebuah keputusan. Mempermudah dan mempercepat perolehan data beasiswa tidak mampu.

Manfaat Penelitian ini adalah Menerapkan sistem berbasis komputerisasi pada Prodi Sistem Informasi Universitas Islam Indragiri. Pemilihan beasiswa tidak mampu lebih transparan dan bisa dipertanggung jawabkan. Mempercepat serta mempermudah dalam mendapatkan data mahasiswa yang berhak mendapatkan beasiswa tidak mampu. 


\section{LANDASAN TEORI}

Sistem pendukung keputusan (Decision Support Sistem / DSS) merupakan sistem informasi, pemodelan, dan pemanipulasian data. Sistem itu digunakan untuk membantu pengambilan keputusan dalam situasi yang semiterstruktur (hanya sebagian masalahnya mempunyai jawaban yang jelas tersedia dengan prosedur yang disetujui bersama) dan situasi yang tidak terstruktur (keputusan yang pengambilan keputusannya harus memberikan penilaian, evaluasi, dan pengertian untuk memecahkan masalahnya), di mana tak seorang pun tahu secara pasti bagaimana keputusan seharusnya dibuat (Alter, 2002).

\subsection{Metode Tsukamoto}

Metode Tsukamoto merupakan perluasan dari penalaran monoton. Pada metode Tsukamoto, setiap konsekuen pada aturan yang berbentuk IF-Then harus dipresentasikan dengan suatu himpunan fuzzy dengan fungsi keanggotaan yang monoton. Sebagai hasilnya, output hasil inferensi dari tiap-tiap aturan diberikan secara tegas (crisp) berdasarkan a-prediket (fire strength). Hasil akhirnya diperoleh dengan menggunakan rata-rata terbobot (Kusumadewi dan Purnomo, 2010).

\section{ANALISA DAN PERANCANGAN}

Tabel 1. Tabel Himpunan Fuzzy

\begin{tabular}{|c|c|c|c|}
\hline & VARIABEL & HIMPUNAN & DOMAIN \\
\hline \multirow{18}{*}{ INPUT } & \multirow{5}{*}{ IPK } & sangat kurang & $0-2$ \\
\hline & & kurang & $2-2,50$ \\
\hline & & cukup & $2,50-3$ \\
\hline & & tinggi & $3-3,50$ \\
\hline & & sangat tinggi & $3,50-4$ \\
\hline & \multirow{5}{*}{ Penghasilan Orang Tua } & sangat kecil & $0-500.000$ \\
\hline & & kecil & $500.000-1.000 .000$ \\
\hline & & sedang & $1.000 .000-1.500 .000$ \\
\hline & & besar & $1.500 .000-2.000 .000$ \\
\hline & & sangat besar & $2.000 .000-2.500 .000$ \\
\hline & \multirow{5}{*}{ Tanggungan Orang Tua } & sangat sedikit & $0-1$ \\
\hline & & sedikit & $1-2$ \\
\hline & & sedang & $2-3$ \\
\hline & & banyak & $3-4$ \\
\hline & & sangat banyak & $4-5$ \\
\hline & \multirow{3}{*}{ Keaktifan } & kurang aktif & $0-1$ \\
\hline & & aktif & $1-2$ \\
\hline & & sangat aktif & $2-4$ \\
\hline \multirow{2}{*}{ OUTPUT } & \multirow{2}{*}{ Penerima Beasiswa } & tidak & $0-80$ \\
\hline & & ya & $80-100$ \\
\hline
\end{tabular}

\subsection{Pembentukan Himpunan Fuzzy}

Pembentukan Hipunan Fuzzy untuk sistem pendukung keputusan pemilihan penerima mahasiswa sebagai berikut : 
Indeks Prestasi Komulatif

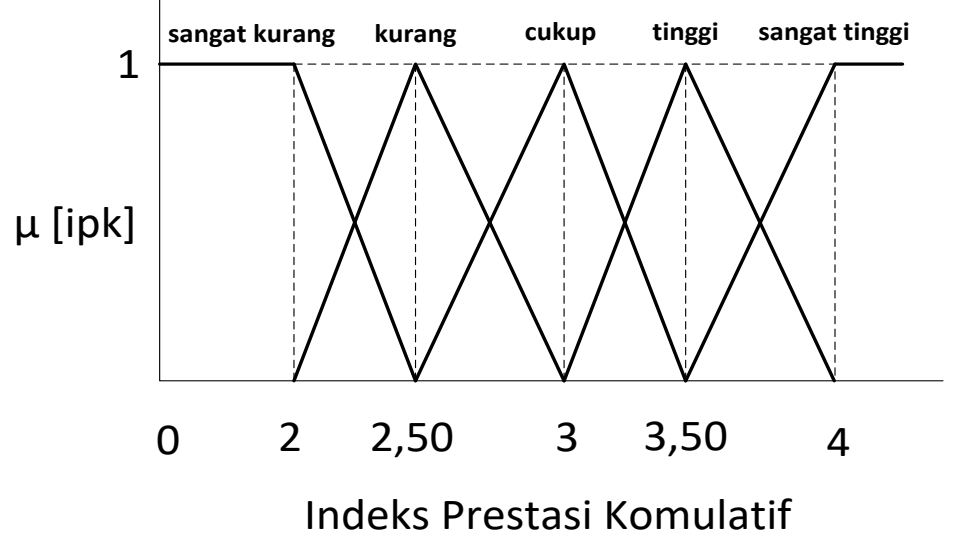

\section{Gambar 1. Fungsi Keanggotaan Variabel Indeks Prestasi Komulatif}

Rumus mecari derajat keanggotaan variabel indeks prestasi komulatif :

$\mu$ sangatkurang[ipk $= \begin{cases}1, & \text { ipk } \leq 2 \\ (2,50-\text { ipk }) / 0,50, & 2 \leq \text { ipk } \leq 2,50 \\ 0, & \text { ipk } \geq 2,50\end{cases}$
$\mu$ kurang[ipk] $\quad \begin{cases}1, & \text { ipk } \leq 2 \text { atau ipk } \geq 3 \\ (\text { ipk- } 2) / 0,50, & 2 \leq \text { ipk } \leq 2,50 \\ (3-\text { ipk }) / 0,50, & 2,50 \leq \mathrm{ipk} \leq 3\end{cases}$

$\mu$ cukup $[$ ipk $]= \begin{cases}1, & \text { ipk } \leq 2,50 \text { atau ipk } \geq 3,50 \\ (\text { ipk-2,50)/0,50, } & 2,50 \leq \text { ipk } \leq 3 \\ (3,50-\text { ipk }) / 0,50, & 3 \leq \text { ipk } \leq 3,50\end{cases}$

$\mu$ tinggi[ipk $]= \begin{cases}1, & \mathrm{ipk} \leq 3 \text { atau ipk } \geq 4 \\ (\text { ipk-3)/0,50, } & 3 \leq \mathrm{ipk} \leq 3,50 \\ (4-\text { ipk }) / 0,50, & 3,50 \leq \mathrm{ipk} \leq 4\end{cases}$

$\mu$ sangattinggi $[$ ipk $]= \begin{cases}0, & \text { ipk } \leq 3,50 \\ (\text { ipk- } 3,50) / 0,50, & 3,50 \leq \text { ipk } \leq 4 \\ 1, & \text { ipk } \geq 4\end{cases}$

Pendapatan Orang Tua

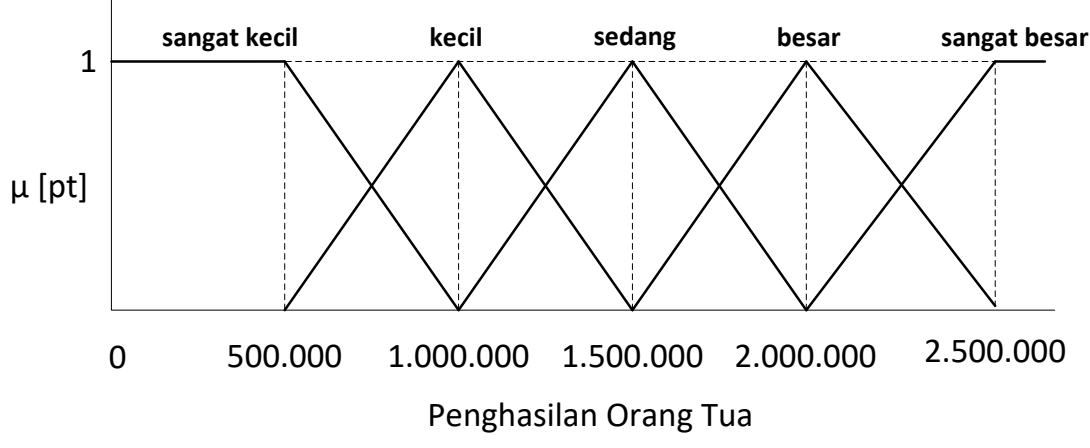

\section{Gambar 2. Fungsi Keanggotaan Variabel Penghasilan Orang Tua}

Rumus mencari derajat keanggotaan variabel penghasilan orang tua :

Syahputra, Sistem Pendukung Keputusan Untuk Menentukan Penerimaan Beasiswa Tidak Mampu Program Studi Sistem Informasi Iniversitas Islam Indragiri 


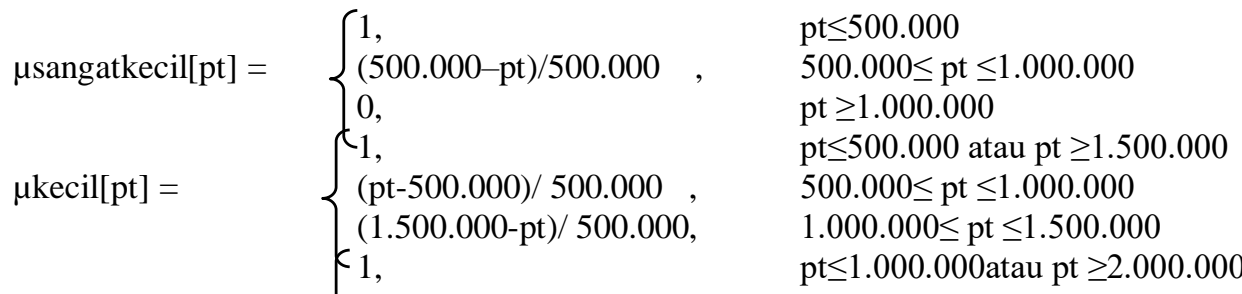

$$
\begin{aligned}
& \mu \text { sedang }[\mathrm{pt}]=\quad \begin{cases}1,1.000 .000) / 500.000, & 1.000 .000 \leq \mathrm{pt} \leq 1.500 .000\end{cases} \\
& \text { (2.000.000-pt)/500.000, } \quad 1.500 .000 \leq \mathrm{pt} \leq 2.000 .000
\end{aligned}
$$

$\mathrm{pt} \leq 1.500 .000$ atau $\mathrm{pt} \geq 2.500 .000 \mu$ besar $[\mathrm{pt}]=(\mathrm{pt}-$ (3.9)

$2.000 .000 \leq \mathrm{pt} \leq 2.500 .000$

$\mathrm{pt} \leq 2.000 .000$

$2.000 .000 \leq \mathrm{pt} \leq 2.500 .000$

$\mathrm{pt} \geq 2.5000 .000$

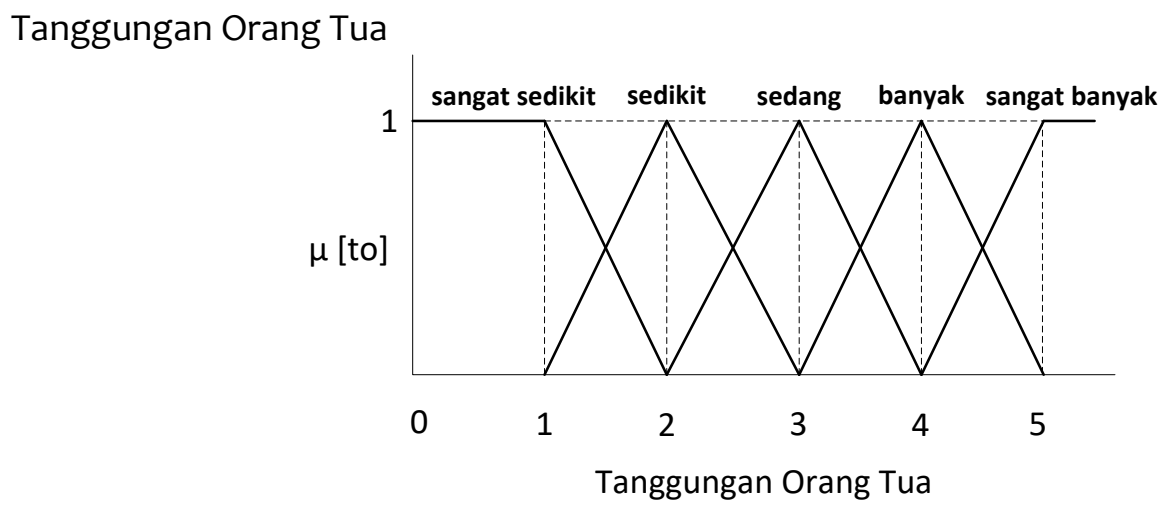

\section{Gambar 3. Fungsi Keanggotaan variabel Tanggungan Orang Tua}

\begin{tabular}{|c|c|c|}
\hline$\mu$ sangatsedikit $[$ to $]=$ & $\left\{\begin{array}{l}1, \\
(2-\text { to }) / 1, \\
0,\end{array}\right.$ & $\begin{array}{l}\text { to } \leq 1 \\
1 \leq \text { to } \leq 2 \\
\text { to } \geq 2\end{array}$ \\
\hline$\mu$ sedikit $[$ to $]=$ & $\left\{\begin{array}{l}1, \\
\text { (to-1)/1 } \\
\text { (3-to)/1, }\end{array}\right.$ & $\begin{array}{l}\text { to } \leq 1 \text { atau to } \geq 3 \\
1 \leq \text { to } \leq 2 \\
2 \leq \text { to } \leq 3\end{array}$ \\
\hline$\mu$ sedang $[$ to $]=$ & $\left\{\begin{array}{l}1, \\
(\text { to- } 2) / 1, \\
(4-\text { to }) / 1\end{array}\right.$ & $\begin{array}{l}\text { to } \leq 2 \text { atau to } \geq 4 \\
2 \leq \text { to } \leq 3 \\
3 \leq \text { to } \leq 4\end{array}$ \\
\hline$\mu$ banyak $[$ to $]=$ & $\left\{\begin{array}{l}1, \\
(\text { to-3)/1 } \\
(5-\text { to }) / 1\end{array}\right.$ & $\begin{array}{l}\text { to } \leq 3 \text { atau to } \geq 5 \\
3 \leq \text { to } \leq 4 \\
4 \leq \text { to } \leq 5\end{array}$ \\
\hline$\mu$ sangatbanyak $[$ to $]=$ & $\left\{\begin{array}{l}0, \\
(\text { to-4)/1 } \\
1,\end{array}\right.$ & $\begin{array}{l}\text { to } \leq 4 \\
4 \leq \text { to } \leq 5 \\
\text { to } \geq 5\end{array}$ \\
\hline
\end{tabular}

\section{Rumus mencari derajat keanggotaan variabel tanggungan orang tua :}


Keaktifan

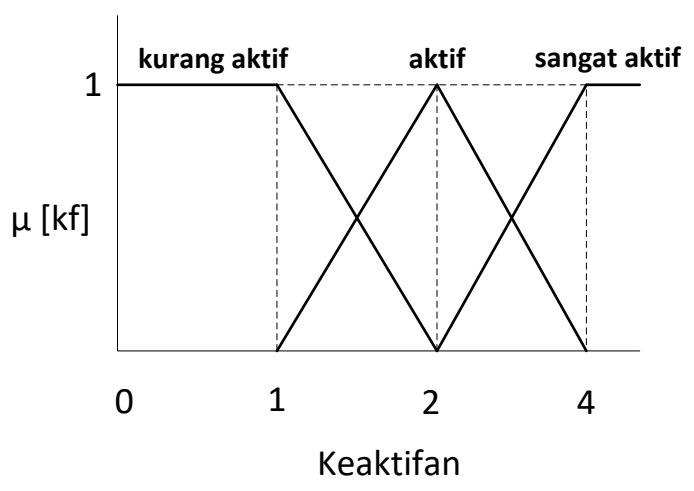

\section{Gambar 4. Fungsi Keanggotaan Variabel Keaktifan}

Rumus mencari derajat keanggotaan variabel keaktifan :

$\begin{array}{ll}\mu \text { kurangaktif[kf] }= & \begin{cases}1, \mathrm{p} & \mathrm{kf} \leq 1 \\ (2-\mathrm{kf}) / 1, & 1 \leq \mathrm{kf} \leq 2 \\ 0, & \mathrm{kf} \geq 2\end{cases} \\ \mu \text { aktif[kf] } \quad \begin{cases}1, & \mathrm{kf} \leq 1 \text { atau } \mathrm{kf} \geq 4 \\ (\mathrm{kf}-1) / 1, & 1 \leq \mathrm{kf} \leq 2 \\ (4-\mathrm{kf}) / 1, & 2 \leq \mathrm{kf} \leq 4\end{cases} \\ \mu \text { sangataktif[kf] }= \begin{cases}0, & \mathrm{kf} \leq 2 \\ (\mathrm{kf}-2) / 2, & 2 \leq \mathrm{kf} \leq 4 \\ 1, & \mathrm{kf} \geq 4\end{cases} \end{array}$

Beasiswa

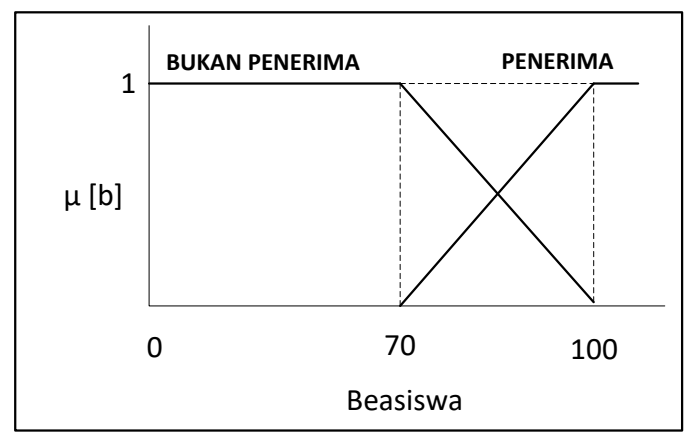

\section{Gambar 5. Fungsi Keanggotaan Variabel Beasiswa}

Rumus mencari derajat keanggotaan variabel beasiswa :

\begin{tabular}{|c|c|c|}
\hline \multirow{2}{*}{$\mu$ bukanpenerima $[\mathrm{b}]=$} & \multirow{3}{*}{$\begin{array}{l}1, \\
(100-b) / 30, \\
0, \\
c_{0}, \\
(b-70) / 30, \\
1\end{array}$} & \multirow{3}{*}{$\begin{array}{l}b \leq 70 \\
70 \leq b \leq 100 \\
b \geq 100 \\
b \leq 70 \\
70 \leq b \leq 100 \\
b \geq 100\end{array}$} \\
\hline & & \\
\hline 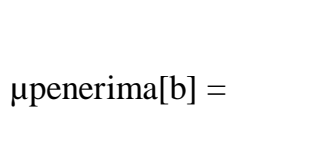 & & \\
\hline
\end{tabular}




\subsection{Pembentukan Rules (Aturan-aturan)}

Aturan-aturan yang terbentuk dari 4 kriteria yang diajukan, terbentuklah sebagai berikut:

[R1] IF indek prestasi komulatif sangat kurang and penghasilan orang sangat kecil and tanggungan orang tua sangat sedikit and keaktifan kurang aktif THEN bukan penerima beasiswa;

[R2] IF indek prestasi komulatif kurang and penghasilan orang kecil and tanggungan orang tua sedikit and keaktifan aktif THEN bukan penerima beasiswa;

[R3] IF indek prestasi komulatif cukup and penghasilan orang sedang and tanggungan orang tua sedang and keaktifan sangat aktif THEN penerima beasiswa;

[R4] IF indek prestasi komulatif tinggi and penghasilan orang besar and tanggungan orang tua banyak and keaktifan kurang aktif THEN penerima beasiswa;

[R5] IF indek prestasi komulatif sangat tinggi and penghasilan orang sangat besar and tanggungan orang tua sangat banyak and keaktifan kurang aktif THEN penerima beasiswa;

[R6] IF indek prestasi komulatif tinggi and penghasilan orang besar and tanggungan orang tua banyak and keaktifan aktif THEN penerima beasiswa;

[R7] IF indek prestasi komulatif sangat tinggi and penghasilan orang sangat besar and tanggungan orang tua sangat banyak and keaktifan aktif THEN penerima beasiswa;

[R8] IF indek prestasi komulatif tinggi and penghasilan orang besar and tanggungan orang tua banyak and keaktifan sangat aktif THEN penerima beasiswa;

[R9] IF indek prestasi komulatif sangat tinggi and penghasilan orang sangat besar and tanggungan orang tua sangat banyak and keaktifan sangat aktif THEN penerima beasiswa;

[R10] IF indek prestasi komulatif sangat kurang and penghasilan orang kecil and tanggungan orang tua sedang and keaktifan kurang aktif THEN bukan penerima beasiswa;

[R11] IF indek prestasi komulatif sangat kurang and penghasilan orang kecil and tanggungan orang tua sedang and keaktifan aktif THEN bukan penerima beasiswa;

[R12] IF indek prestasi komulatif sangat kurang and penghasilan orang kecil and tanggungan orang tua sedang and keaktifan sangat aktif THEN bukan penerima beasiswa;

[R13] IF indek prestasi komulatif kurang and penghasilan orang sedang and tanggungan orang tua banyak and keaktifan kurang aktif THEN bukan penerima beasiswa;

[R14] IF indek prestasi komulatif kurang and penghasilan orang sedang and tanggungan orang tua banyak and keaktifan aktif THEN bukan penerima beasiswa;

[R15] IF indek prestasi komulatif kurang and penghasilan orang sedang and tanggungan orang tua banyak and keaktifan sangat aktif THEN penerima beasiswa;

[R16] IF indek prestasi komulatif sangat tinggi and penghasilan orang besar and tanggungan orang tua sedang and keaktifan aktif THEN penerima beasiswa;

[R17] IF indek prestasi komulatif tinggi and penghasilan orang sedang and tanggungan orang tua sedikit and keaktifan kurang aktif THEN bukan penerima beasiswa;

[R18] IF indek prestasi komulatif sangat kurang and penghasilan orang sangat kecil and tanggungan orang tua sedikit and keaktifan aktif THEN bukan penerima beasiswa;

[R19] IF indek prestasi komulatif sangat kurang and penghasilan orang sangat kecil and tanggungan orang tua sedang and keaktifan sangat aktif THEN bukan penerima beasiswa;

[R2O] IF indek prestasi komulatif kurang and penghasilan orang kecil and tanggungan orang tua sedang and keaktifan sangat aktif THEN bukan penerima beasiswa; 


\subsection{Perancangan Proses}

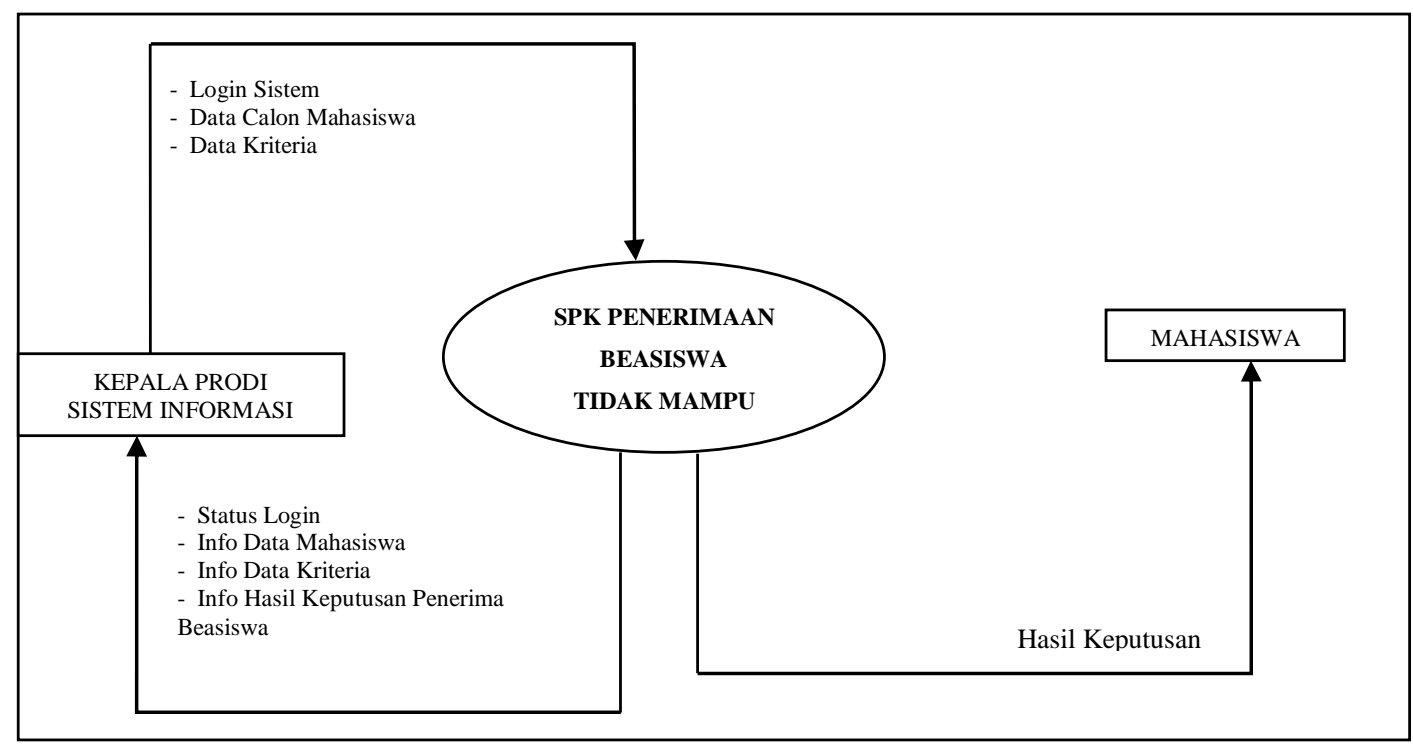

Gambar 6. Konteks Diagram Penerimaan Beasiswa Tidak Mampu

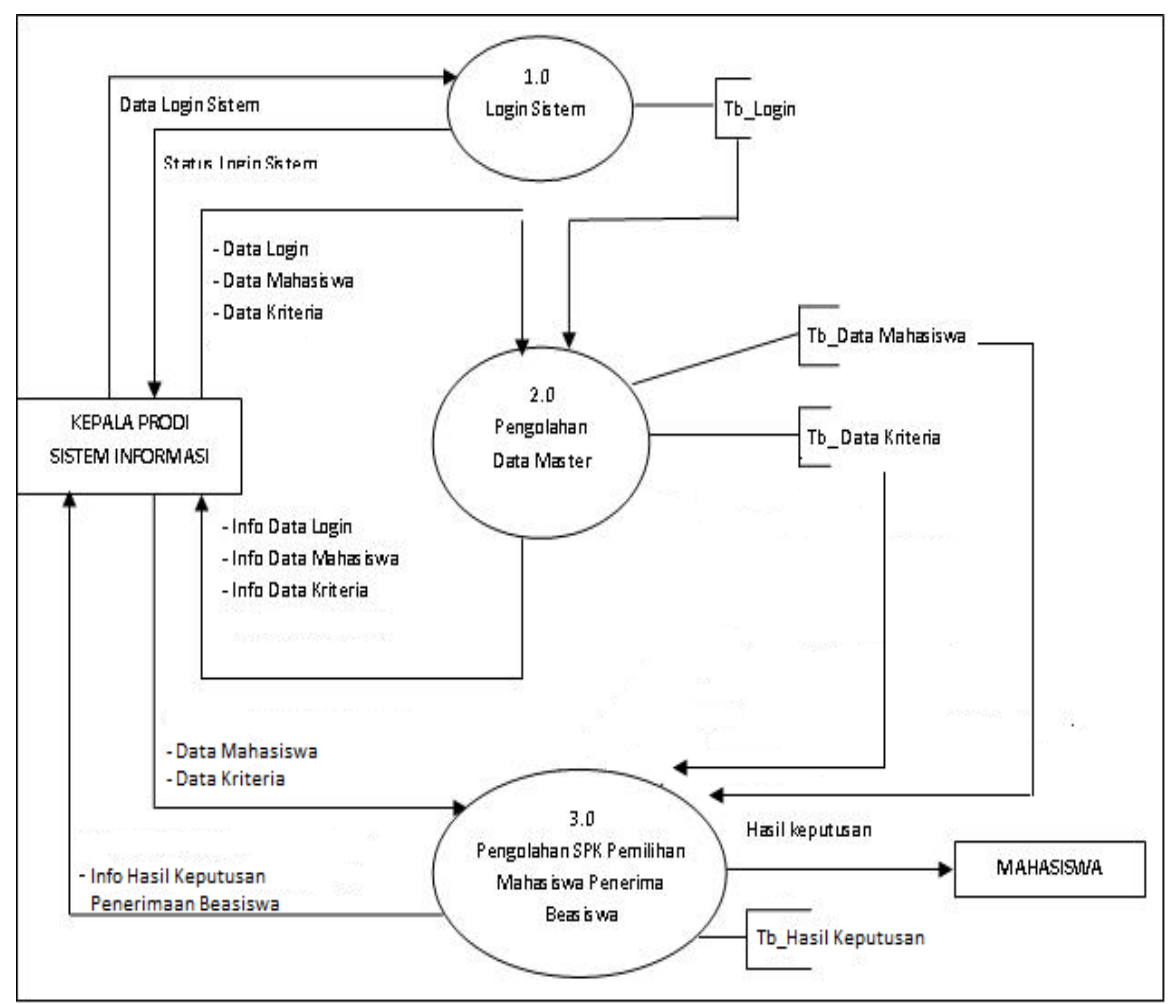

Gambar 7. DFD Level o SPK Mahasiswa Penerima Beasiswa Tidak Mampu 


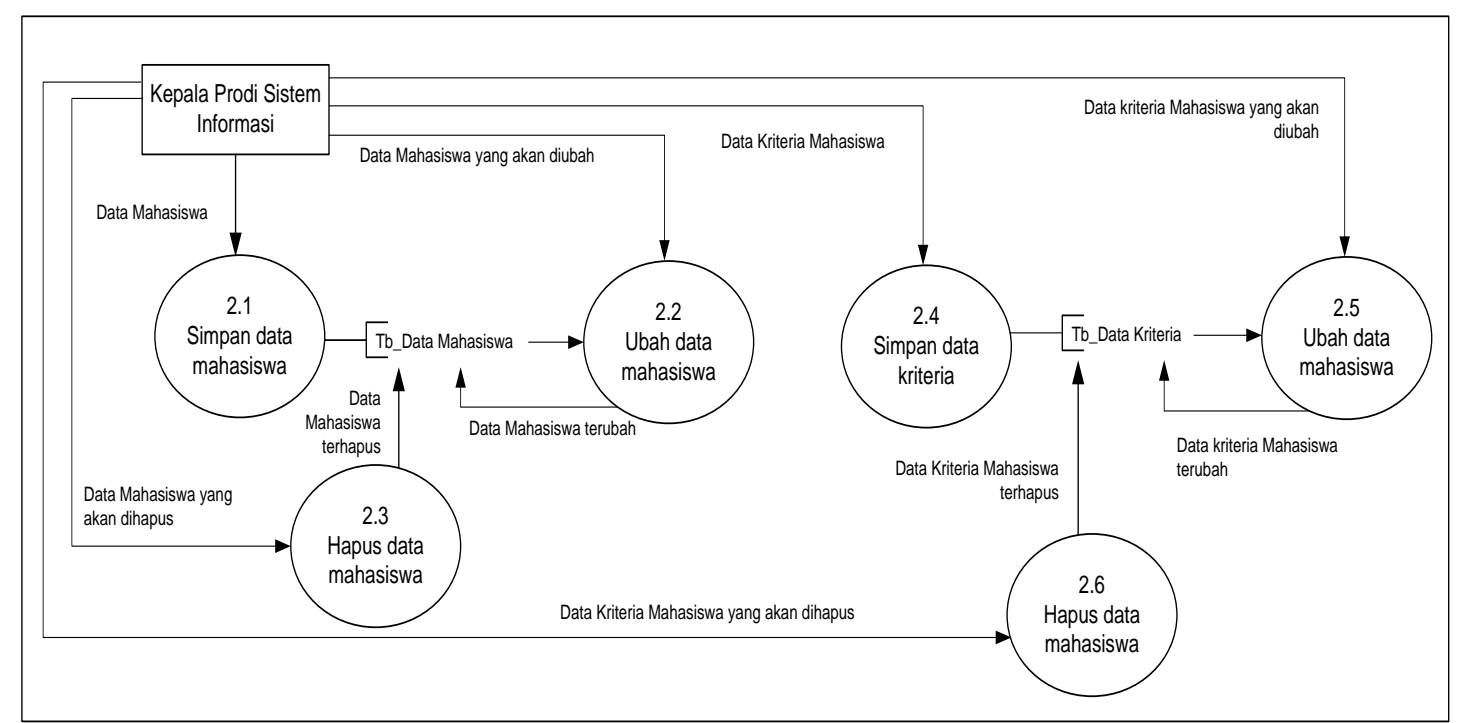

Gambar 8. DFD Level 1 Proses 2.0

\section{IMPLEMENTASI DAN PENGUJIAN SISTEM}

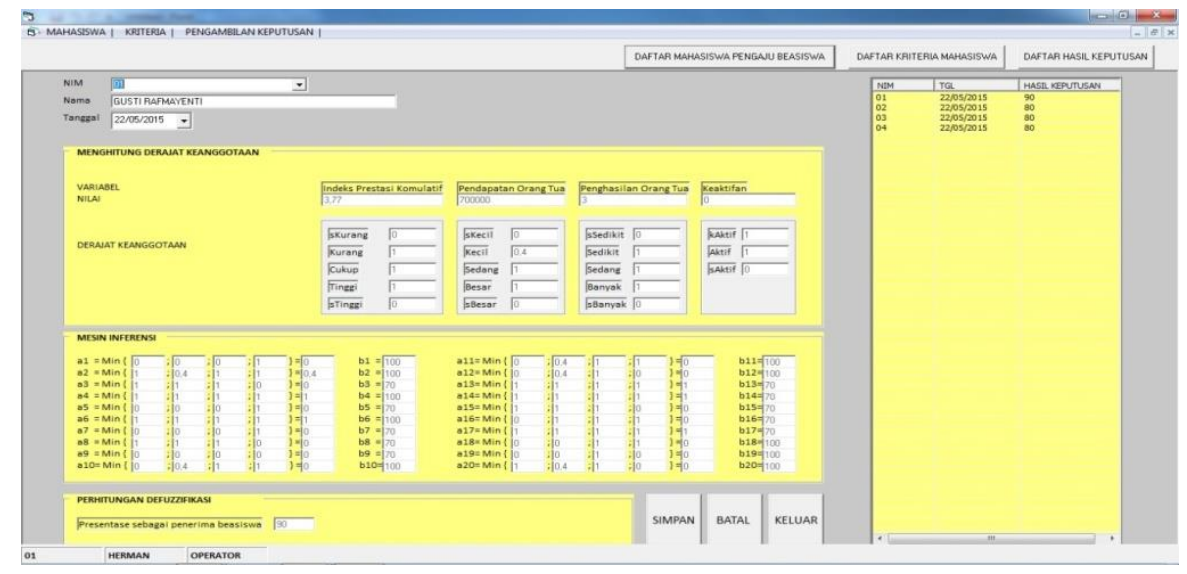

Gambar 9. Form Hasil Keputusan

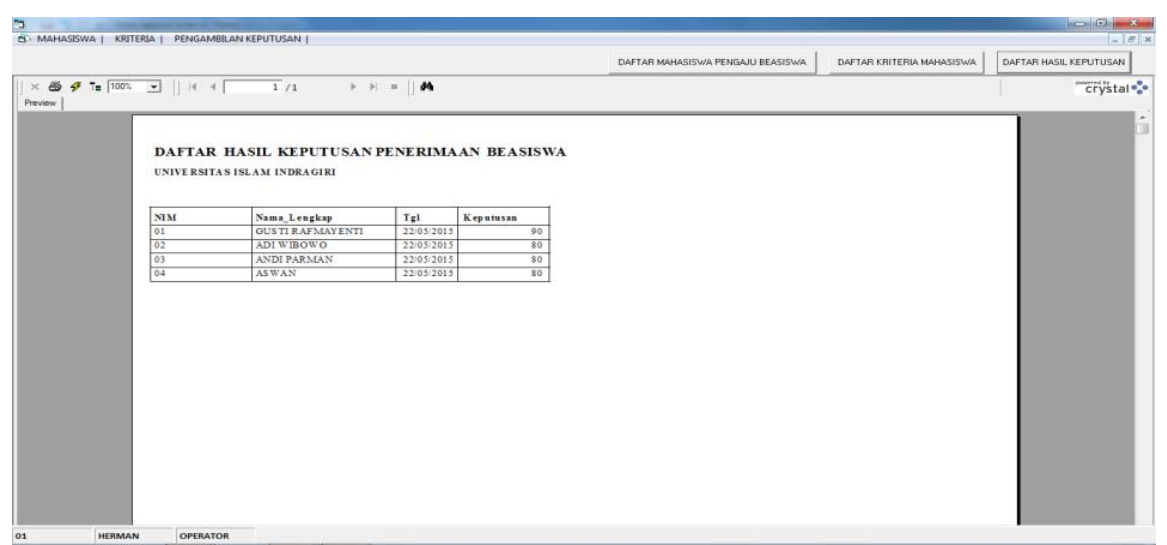

Gambar 10. Laporan Hasil Keputusan 


\section{KESIMPULAN}

\subsection{Kesimpulan}

Diterapkannya sistem pengambilan keputusan berbasis komputerisasi memberikan kemudahan bagi prodi sistem informasi dalam mengambil keputusan untuk menentukan penerima beasiswa.

Diterapkannya kriteria-kriteria oleh prodi sistem informasi sebagai syarat yang wajib dipenuhi oleh setiap mahasiswa yang ingin memperoleh beasiswa tidak mampu.

\subsection{Saran}

Menggunakan sistem komputerisasi sehingga data bisa disimpan di media penyimpanan seperti hard disk backup dan bukannya berupa lembaran-lembaran kertas.

Kepada pembaca atau calon pengembang sistem ini berikutnya untuk mengembangkan sistem yang telah dirancang ini menjadi sistem yang lebih dapat diandalkan dan dapat dimanfaatkan lebih maksimal.

\section{REFERENSI}

Eniyati, Sri. 2009. Perancangan Sistem Pendukung Keputusan untuk Penerimaan Beasiswa dengan Metode SAW (Simple Additive Weighting). Semarang : Jurnal Teknologi Informasi DINAMIK Volume 16. 2011

Handayani, Tri, Wawan Lakaito YS, dan Teguh Susyanto. Sistem Pendukung Keputusan Beasiswa Diklat Dengan Fuzzy MADM : ISSN : 2338-4018

Hamdani, Haviluddin, dan Muhammad Syarif Abdillah. 2011. Sistem Pendukung Keputusan Pembelian Notebook Menggunakan Logika Fuzzy Tahani : Jurnal Informatika Mulawarman Vol. 6 No. 3 September 201198

Jayanti, Sherly, dan Sri Hartati. 2012. Sistem Pendukung Keputusan Seleksi Anggota Paduan Suara Dewasa menggunakan Metode Fuzzy Mamdani. Palangka Raya : IJCCS, VoL6, No.1, January 2012, pp. 55-66. ISSN: 1978-1520

Jogiyanto. 2005. Analisis dan Desain. Yogyakarta : Penerbit Andi

Kusrini. 2007. Konsep dan Aplikasi Sistem Pendukung Keputusan. Yogyakarta : Andi.

Kristanto, Andri. Perancangan Sistem Informasi dan Aplikasinya. Yogyakarta : Grava Media. 2007.

Ladjamuddin, Al- Bahra. 2005. Analisa dan Desain Sistem Informasi. Yogyakarta : Graha Ilmu.

Mulyanto, Edy, T. Sutojo, dan Dr. Vincet Suhartono. 2011. Kecerdasan Buatan. Yogyakarta : Andi

Sholihin, Miftahus, Nurul Fuad dan Nurul Khamiliyah. 2013. Sistem Pendukung Keputusan Penentuan Warga Penerima Jamkesmas Dengan Metode Fuzzy Tsukamoto. Lamongan : Jurnal Teknika Vol. 5 No. 2 September 2013 ISSN No. 2085-0859

Sumiati, dan Shodik Nuryadin. 2013. Sistem Pendukung Keputusan Dalam Menentukan Penilaian Kinerja Dosen Dengan Metode Fuzzy Database Model Mamdani. Banten : ISSN $1412-3762$. ELECTRANS, VOL.12, NO.2, SEPTEMBER 2013 , 161-170. 